\title{
First record of Egeria densa Planch. (Hydrocharitaceae) for the aquatic Flora of Egypt
}

\author{
Eman M. Shamso* and Hasnaa A. Hosni
}

The Herbarium, Botany and Microbiology Department, Faculty of Science, Cairo University, Giza 12613, Egypt.

*corresponding author: e.shamso@yahoo.com \& https://orcid.org/0000-0002-0068-0224

\section{Abstract}

Egeria densa Planch. is reported for the first time for the aquatic flora of Egypt. This species is a South American aquatic plant species considered highly invasive outside of its original range. In Egypt, the species may have been introduced as an aquarium plant and has long been wrongly identified as Elodea canadensis. However, it was collected from wild habitat at the northern lake of Egypt (Idku Lake). The article presents data on the comprehensive morphological and palynological features, distribution, ecological notes, and conservation status in Egypt of the newly recorded taxon, as well as photographs of herbarium samples, were also provided. This species has not been reported in North Africa, except for Algeria. The new record of its presence in Egypt fills the gap in its general distribution in the warm temperate region of the world. Based on the present study Hydrocharitaceae in Egypt, is now represented by 7 genera viz. Halophila, Thalassia, Ottelia, Vallisneria, Elodea, Najas and Egeria. The present data indicate that there are insufficient collections of Egeria densa in Egypt considering that the aquatic flora of Egypt is poorly known.

Keywords: Egeria densa, Egypt, First record, Hydrocharitaceae, Idku Lake

\section{Introduction}

Egeria Planch. (Brazilian waterweed) is a submerged, freshwater, perennial genus of the family Hydrocharitaceae, native to subtropical and temperate South America (Cook \& Urmi-König 1984). Egeria is morphologically distinguished from other Hydrocharitaceae mainly by its paired scale leaves (prophylls) at the base of lateral shoots, intravaginal squamulus with entire margins, leaves with transparent idioblasts (specialized cells lacking chlorophyll) and leaf margins without fiber cells; in addition, the genus shows unisexual flowers, nine stamens, petals much exceeding the sepals; nectaries on male flowers and staminodia on female flowers are yellow or orange (Cook \& Urmi-König 1984; Koehler \& Bove 2001).

The genus comprises three species viz. E. densa Planch., E. najas Planch. and E. heterostemon S. Koehler \& C.P. Bove. Egeria densa is distinguished from the other species by its male flowers having homogenous stamens with filaments clavate and strongly pappilose; staminodes somewhat more attenuate to the apex and bearing a shorter stalk up to $0.2 \mathrm{~mm}$ (Koehler \& Bove 2001).

Egeria densa Planch. has been introduced in many countries as aquarium plants. However, it has been escaped from cultivation and become naturalized and invasive in many warm temperate and cold subtropical regions of the world. It is native to the coast of southeastern Brazil, Argentina, and Uruguay (Yarrow et al., 2009). The plant is considered naturalized in the Eastern United States (Cook \& Urmi-König 1984), North America (Les \& Mehrhoff 1999), Asia ((Haramoto \& Ikusimsa 1988, Alfasane et al. 2010), Australia (Roberts et al. 1999), Africa (Maire 1952; Simpson 1989; Coetzee et al. 2011) and Europe (Medina \& Cirujano 1995; Sergin 2008; Kikodze et al. 2010; Hussner 2012; Medvecká et al. 2012; Millane \& Caffrey 2014; Wasowicz et al., 2014; Fominykh et al., 2016 and Rimac et al., 2018). According to Yarrow et al. (2009), E. densa 
has been successful as an introduced species and a highly efficient invader due to its high biomass production, fast vegetative reproduction and efficient dispersal, and he considered it as an ecosystem engineer that is capable of modifying or regulating important ecosystem process by preventing the resuspension of sediments and controlling the growth of phytoplankton.

In Egypt, the number of aquatic weed species in the Nile system is about 50, belonging to 28 genera and 22 families (Boulos 2009; Soliman et al. 2018): only seven taxa are native in to Egypt. In the last decades, some of these species disappeared such as Vallisneria spiralis L., Elodea Canadensis Michx., Wolffia hyalina (Delile) Hegelm. and Alisma plantago-aquatica L., this can be attributed to human activities and continuous cleaning of the water channels (El Ghani et al. 2010). Of these, family Hydrocharitaceae is represented by six genera of which Halophila, Thalassia, Najas are native, while Ottelia, Vallisneria, and Elodea are exotic; these genera included 11 species inhabiting both saline and fresh water (Täckholm et al. 1941; Täckholm 1974; El Hadidi \& Fayed 1994/95; Boulos 2005 \& 2009). This paper aims to report Egeria as a new record for the aquatic flora of Egypt and to present a new distributed area for this taxon.

\section{Materials and Methods}

During the taxonomic revision of the specimens belonging to the family Hydrocharitaceae kept at the different Herbaria in Egypt [Cairo University (CAI), the Agricultural Research Centre, Flora \& phytotaxonomy Herbarium (CAIM), National Research Centre, Plant Systematic Herbarium (CAIRC) and Sohag University (SHG)]. The specimens were identified by relevant literatures (Cook \& Urmi-König, 1984; Simpson, 1989); as well virtual Herbaria available on line: (http://apps.kew.org), Africa plant database (www.tropicos.org), New York Botanical Garden (NYBG), Harvard University Herbaria \& Libraries (HUH) and JSTOR global plants database (http://plants.jstor.org) acronyms follows Index Herbarium (http://sweetgum.nybg.org/ih). Brief description, phenology and ecology of the newly recorded species have been provided along with photographs for the taxon.

Pollen grains were also studied to confirm the identification. Samples of pollen were taken from mature anthers. For light microscopy (LM), anthers were boiled for a few minutes in water, macerated in a few drops of an aqueous $10 \%$ solution of $\mathrm{KOH}$ on a clean slide, then stained with Safranin (1\% Safranin solution in 50\% ethanol), mounted in glycerin jelly and observations were made with a Sterico research microscope under (E $40,0.65$ ) using a $16 x$ eye piece. For SEM studies, pollen grains and a piece of leaf margin were mounted onto stubs with double sided adhesive, and then these stubs were sputter-coated with gold (Ion-sputter JFC1100). After coating, they were examined using JEOL JSM 5400LV scanning electron microscope at $15 \mathrm{KV}$, at the Electron Microscopy Unit, National Research Center, Doki, Giza. The description of pollen follows the terminology of Hesse et al. 2009.

\section{Results and Discussion}

During the preparation of a taxonomic revision of Hydrocharitaceae in Egypt, the authors came across with Egeria densa Planch. collected previously from different localities in different seasons. These specimens were cross-checked with the description provided with some literatures (Cook \& Urmi-König 1984; Simpson 1989 and Tanaka et al. 2004). This newly recorded taxon was wrongly been identified as Elodea canadensis Michx., a closely related taxon, which it differs in having larger leaves (10-30 $\mathrm{mm}$ long) arranged in whorls of four or more, not three, and in having more conspicuous flowers with larger broader petals $(8-10 \times 3-6 \mathrm{~mm})$.

\section{Taxonomic treatment:}

Egeria densa Planch. in Ann. Sci. Nat. ser. 3, 11:80 (1849). (Fig. 1)

Type: Argentina, in ditione Platensi, prope Bonariam, Tweedie 10 (K, holotype)

Synonyms: Anacharis densa (Planch.) Vict. Contr. Lab. Bot. Univ. Montréal 18: 41 (1931). 
- Elodea densa (Planch.) Casp. Monatsber. Königl. Preuss. Akad. Wiss. Berlin 1857: 49 (1857).

- Philotria densa (Planch.) Small, Man. S.E. Fl. 28 (1933).

Dioecious, submerged freshwater herbs, growing in shallow water. It grows up to 1.5 meters. Stem monomorphic, elongate, cylindrical, trailing and producing roots at intervals along the stem, sometimes branched. Branches one per axil, subtended at the base by a pair of scale-like brownish leaves (prophylls), ovate, $2-3 \times 2-3.5 \mathrm{~mm}$. Internodes short, up to $10 \mathrm{~mm}$ long, give it a very leafy appearance. Leaves sessile arranged in whorls of four to five, narrowly oblong to linearlanceolate, $10-30 \times 2-3(-5) \mathrm{mm}$, spreading, flaccid, bright green, somewhat translucent, one-veined; gradually attenuate to acute apex; margin shallowly serrulate. Apex and margin bearing unicellular, thick-walled prickle hairs (Fig. 2A). Flowers unisexual; male spathes solitary in leaf-axil, sessile, narrowly ovoid, 8-10×3-4 mm, translucent; male flowers $2-4$ in each spathe, pedicellate, pedicel long 40-80 mm long. Sepals 3, free, green, ovate and boat-shaped,
$2.5-3 \times 1.2-2.3 \mathrm{~mm}$, membranous; petals 3 , free, white, delicate, widely elliptic, 8-10×3-6mm. Stamens 9, homogeneous, $5-7 \mathrm{~mm}$ long; filaments clavate and papillose above, constricted below the yellow anthers; Pollen grains monads, isodiametric, medium sized, spheroidal, 45$50 \mu \mathrm{m}$ in diameter, inaperturate, exine sculpture echinate with fine granules in between (Fig. 2B-D). Nectaries obscure.

According to Rimac et al. (2018) only male flowers have generally been observed across the whole introduced range, while the plant reproduces via vegetative shoot fragments. In Egypt, the plant has not been observed with female flowers and fruits.

Phenology. - Flowering period in Egypt: August - September

Representative specimens. - Idku Lake, Nile Delta, 19.9.1977; A. Fiky s.n. (CAI)- Beheira Province, Idku, 19.8.1987, A. Amer 12743 (CAI) -Faculty of Science Garden, Alexandria, 1.6.1975; A. Gazzar s.n. (CAI)Giza; 10.4.1931; E. Greiss s.n. (CAI) - Giza, Faculty of Science garden, 14.3.1936; A. Soliman s.n. (CAI).

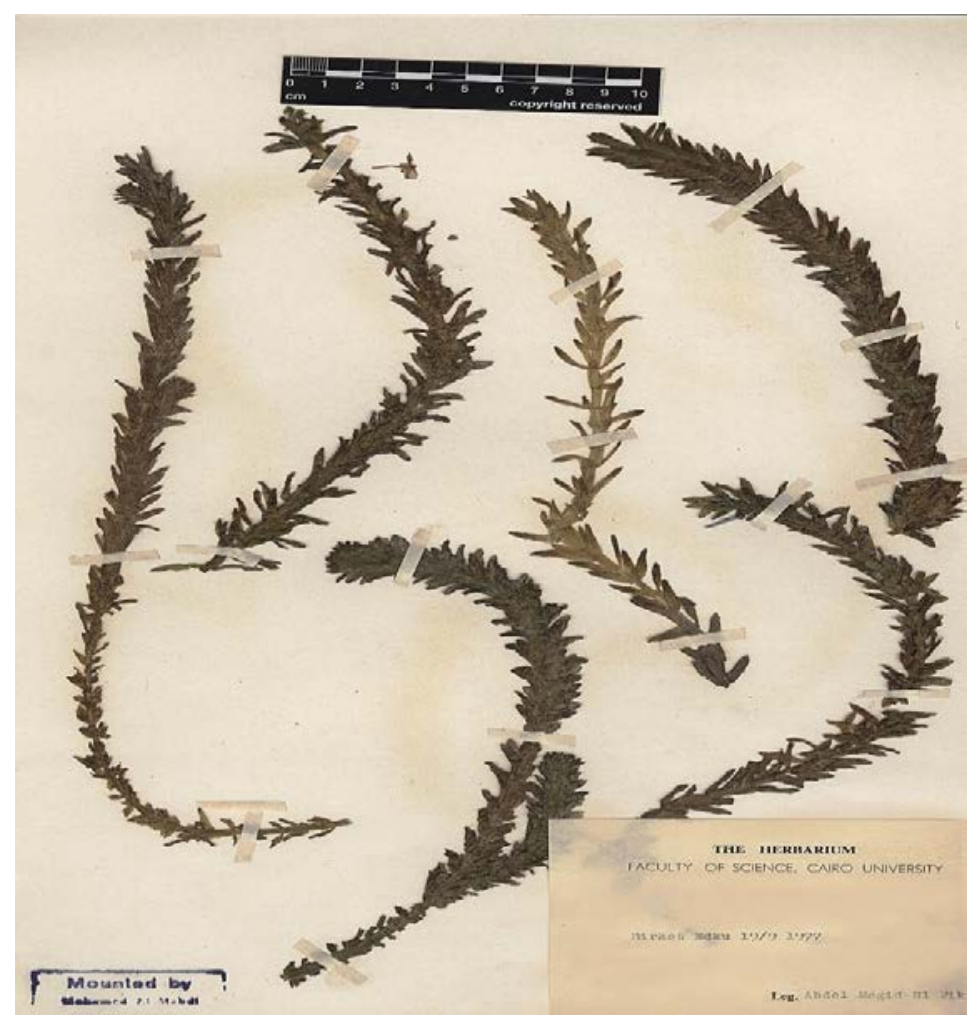

Fig. 1. Image of Herbarium specimen of Egeria densa (CAI) 

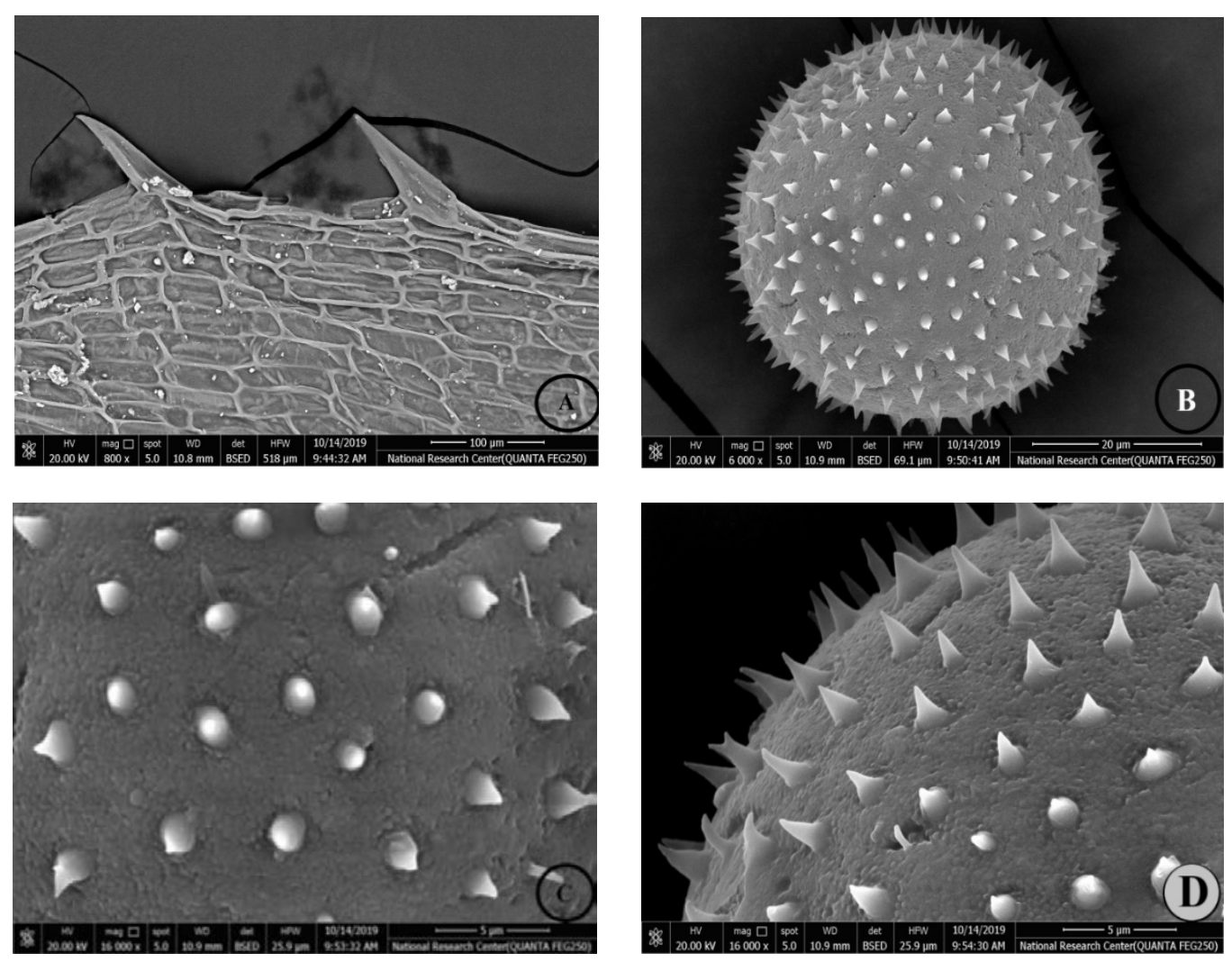

Fig. 2- SEM micrographs of Hair and Pollen grains of Egeria densa. A: Unicellular, prickle-hairs on the margin of the leaf. B: Whole Pollen grain (Spheroidal \& symmetric pollen). C \& D: Exine sculpture (echinate with fine granules in between).

Habitat and Ecology. - Egeria densa is frequently dominant in clear water with low light attenuation and is relatively constant in the range between $16^{\circ} \mathrm{C}$ and $28^{\circ} \mathrm{C}$ (Carrillo et al. 2006, Barko \& Smart 1981). The species was found in Lake Edku (Nile Delta) in clear and slow flowing water associated with Lemna gibba L., Potamogeton crispus L., Najas marina L.

The Lake Edku is one of the northern coastal lakes in Egypt, located at the western part of the Nile Delta east of Alexandria and west of Rosetta (Rashid), Situated at $30 \mathrm{~km}$ NE of Alexandria. It is one of four coastal deltaic lakes that are connected to the Mediterranean Sea; between altitudes $30^{\circ} 8^{\prime}$ to $30^{\circ} 28^{\prime} \mathrm{E}$ \& latitudes $31^{\circ} 10^{\prime}$ to $31^{\circ} 8^{\prime} \mathrm{N}$. It has an area of $126 \mathrm{~km}^{2}$ and water depth ranging from $50-150 \mathrm{~cm}$. The Lake receives huge amounts of drainage water from three main drains namely, Edku, Bousaly, El-Khairy and Berseek, which open into the eastern basin of the lake (Abdel Halim et al. 2013; Alnagaawy et al. 2018). The lake suffers from many problems as drying up large areas from its water body, over-fishing, chemical and biological pollution and drainage of untreated sewage water in it. Its area has decreased from $28.5 \times 10^{3}$ to about $12 \times 10^{3}$ Fadden's as a result of agricultural reclamation (Shaltout et al. 2005; Abdel Halim et al. 2013).

Taxonomic affinities. - Based on molecular studies, Egeria is closely related to genus Elodea and treated as sister group of Apalanthe (Les et al. 1997; Koehler \& Bove 2001). The invasive aquatic plants Hydrilla and Lagarosiphon are also strongly resemble the genus Egeria, it can be distinguished from the other genera by its larger size, showy flowers, the leaf whorls and the longest leaves (Simpson 1989).

Conservation Status: The southern part of Lake Edku was dried up and reclaimed with 
some parts of out skirting deserts to increase the area of the arable land (El Hadidi 2000); in addition, the climatic changes and environmental factors and pollution affect the diversity and distribution of macrophytic vegetation in the Nile Delta of Egypt (ElGhani et al., 2010). These may lead to the disappearance of this species from Egypt.
Distribution: Native to Eastern South America (SE Brazil, coast of Argentina, and coast of Uruguay), now widely introduced as aquarium plant and naturalized in other parts of the world including N America, Europe, Asia (Japan, Bangladesh, Indonesia, Nepal), Africa (Algeria, Kenya, South Africa) and Australia. In Egypt, here recorded from the Nile Delta, Lake Edku. (Fig. 3).

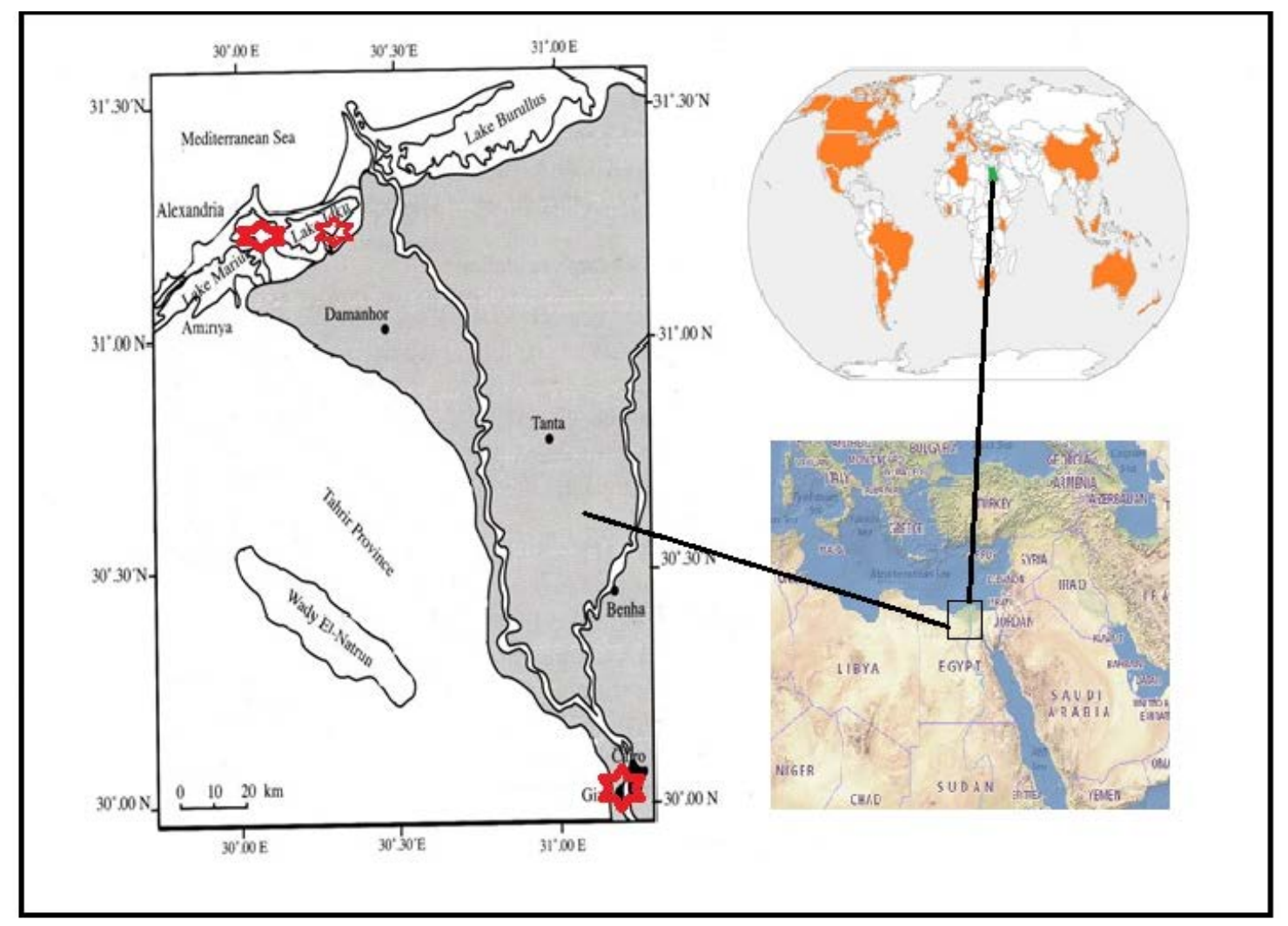

Fig. 3. Distribution map of Egeria densa in the world and in Egypt (

\section{Conclusion}

This species may have been introduced to Egypt through introduction as aquarium plant as it was found growing mostly in gardens. However, some were collected from wild habitat at the northern lake of Egypt (Idku Lake, altitudes $30^{\circ} 8^{\prime}$ to $30^{\circ} 28^{\prime} \mathrm{E}$ \& latitudes $31^{\circ}$ $10^{\prime}$ to $31^{\circ} 8 \mathrm{~N}$ ), which receive the main bulk of drainage water from the Nile Delta. This species has not been reported yet in the North Africa, except for from Algeria (Maire 1952) and is the first record in Egypt. The new record of its presence in Egypt fills the gap in its general distribution in the warm temperate region of the world. Based on the present study, the Hydrocharitaceae are now represented by 7 genera viz. Halophila, Thalassia, Ottelia, Vallisneria, Elodea, Najas and Egeria in Egypt. The present data indicates that there are insufficient collections of Egeria densa in Egypt. Considering that the aquatic flora of Egypt is poorly known, the distribution of the Egeria densa in this study may be a much larger than currently known; more work is needed.

\section{Acknowledgment}

The authors thank to Dr. Amal Hosny, the Herbarium, Botany \& Microbiology Department, Faculty of Science, Cairo University for the critical revision of the manuscript. 


\section{References}

Abdel Halim, A.M., Mahmoud, M.G.O., Guerguess, M.S. \& Tadros, H.R.Z., 2013. Major constituents in Lake Edku water, Egypt. Egyptian Journal of Aquatatic Research. 39: 13-20

Alfasane, M.A., Khondker, M., Islam, M.S. \& Bhuiyan, M.A.H., 2010. Egeria densa Planchón (Hydrocharitaceae): A new angiospermic record for Bangladesh. Bangladesh Journal of Plant Taxonomy 17: 13.

Alnagaawy, A.M., Sherif, M.H., Mohammed, G.A. \& Shehata, A.S., 2018. Impact of industrial pollutants on some water quality parameters of Edku, Mariout lakes and the Nile River. International Journal of Environment. 7(1): 1-15

Barko, J.W. \& Smart. R.M., 1981. Comparative influences of light and temperature on the growth metabolism of selected submerged freshwater macrophytes. Ecological Monograph. 51(2): 219-236.

Boulos, L., 2005. Hydrocharitaceae in L.Boulos. Flora of Egypt. vol.4. Monocotyledons. Al Hadara publishing, Cairo, Egypt.

Boulos, L., 2009. Flora of Egypt Checklist. Revised Annotated Edition. Al Hadara publishing, Cairo, Egypt.

Carrillo, Y., Guarin, A. \& Guillot, G., 2006. Biomass distribution, growth and decay of Egeria densa in a tropical high-mountain reservoir (NEUSA Colombia). Aquatica Botanica 85:7-15.

Coetzee, J.A., Bownes, A. \& Martin, G.D., 2011. Prospectus for the biological control of submerged macrophytes in South Africa. African Entomology.19:469-487.

Cook, C.D. \& Urmi-König, K., 1984. A revision of the genus Egeria (Hydrocharitaceae). Aquatica Botanica. 19:73-96

El-Ghani, M.A., El-Fiky, A.M., Soliman, A. \& Khattab, A., 2010. Environmental relationships of aquatic vegetation in the fresh water ecosystem of the Nile Delta, Egypt. African Journal of Ecology. 49:103-118

El Hadidi, M.N., 2000. Flora Aegyptiaca. Vol. 1 (1). Palm Press \& Cairo University.
El Hadidi, M.N. \& Fayed, A.A., 1994/95. Materials for Excursion Flora of Egypt (EFE). Taeckholmia 15:179-180.

Fominykh, A.S., Mukhutdinov, V.F. \& Kipriyanova, L.M., 2016. Findings of Brazilian Elodea in cooling ponds of the Verkhnii Tagil Power Plant (Middle Urals). Russian Journal of Biological Invasions 7: 189-194.

Haramoto, T. \& Ikusima, I., 1988. Life cycle of Egeria densa Planch., an aquatic plant naturalized in Japan. Aquatica Botanica. 30: 89-403, doi.org/10.1016/0304-3770(88) 90070-8.

Hesse, A., Halbritter, H., Zetter, R., Weber, M., Buchner, R., Andrea, F. \& Ulrich, S., 2009. "Pollen Terminology". An illustrated Handbook. Springer Wein, New York.

Hussner, A., 2012. Alien aquatic plant species in European countries. Weed Research. 52:297-306

Kikodze, D., Memiadze, N., Kharazishvili, D., Manvelidze, Z. \& Muller-Schaerer, H., 2010. The alien flora of Georgia. Joint SNSF SCOPES and FOEN publication, $36 \mathrm{pp}$.

Koehler, S. \& Bove, C.P., 2001. Hydrocharitaceae from Central Brazil: A New Species of Egeria and a Note on Apalanthe granatensis. Novon 11:63-66.

Les, D.H. \& Mehrhoff, L., 1999. Introduction of nonindigenous aquatic vascular plants in southern New England: a historical perspective. Biological Invasions 1:281-300, https://doi.org/10.1023/A:1010086232220.

Les, D.H., Cleland, M.A. \& Waycott, M., 1997. Phylogenetic studies in Alismatidae, II: Evolution of marine angiosperms (sea grasses) and hydrophily. Systematic Botany 22:443463.

Maire, R.C.J.E., 1952. Flore de l'Afrique du Nord (Maroc, Algérie, Tunisie, Tripolitaine, Cyprénaique et Sahara) Vol. 1. Paris. Pp. 223228.

Medina, L. \& Cirujano, S.M., 1995. Egeria densa Planchon (Hydrocharitaceae), naturalized in Spain and Ludwigia natans Elliot (Onagraceae), a xenophyte new to European flora. Anales del Jardin Botánico de Madrid 53(1): 140-141. 
Medvecká, J., Kliment, J., Májeková, J., Halada, L., Zaliberová, M., Gojdičová, E., Feráková, V. \& Jarolimek, I., 2012. Inventory of the alien flora of Slovakia. Preslia 84(2):257-309

Millane, M. \& Caffrey, J., 2014. Risk Assessment of Egeria densa. Inland Fisheries Ireland and the National Biodiversity Data Centre, Ireland.

Rimac, A., Stanković, I., Alegro, A., Gottstein, S., Koletić, N., Vuković, N., Šegota, V. \& Žižić-Nakić, A., 2018. The Brazilian Elodea (Egeria densa Planch.) invasion reaches Southeast Europe. BioInvasions Records.7(4):381-389. http://doi.org/10.3391/bir.2018.7.4.05

Roberts, D.E., Church, A.G. \& Cummins, S.P., 1999. Invasion of Egeria into the Hawkesbury-Nepean River, Australia. Journal of Aquatic Plant Management. 37:3134.

Seregin, A.P., 2008. Contribution to the vascular flora of the Sevastopol area (the Crimea): a checklist and new records. Flora Mediterranea 18:171-246.

Shaltout, K.H., Ali, M.M., Hassan, L.M. \& Galal, T.M., 2005. Habitat and vegetation of Lake Edku, Egypt. Taeckholmia 25: 61-90

Simpson, D., 1989. Hydrocharitaceae in R.M.Polhill (ed.). Flora of Tropical East Africa. Royal Botanic Gardens, Kew.
Soliman, A.T., Hamdy, R.S. \& Hamed, A.B., 2018. Ludwigia stolonifera (Guill. \& Perr.) P.H. Raven, Insight into its phenotypic plasticity, habitat diversity and associated species. Egyptian Journal of Botany. 58(3): 605-626.

Tanaka, N., Uehera, K. \& Murata, J., 2004. Correlation between pollen morphology and pollination mechanisms in the Hydrocharitaceae. Journal of Plant Research.117:265-276.

Täckholm, V., 1974. Students' Flora of Egypt. ed. 2. Cairo University, Egypt

Täckholm, V., Täckholm, G. \& Drar, M., 1941. Flora of Egypt. vol. 1. Bulletin Faculty of Science.

Wasowicz, P., Przedpelska-Wasowicz, E.M., Guŏmundsdóttir, L. \& Tamayo, M., 2014. Vallisneria spiralis and Egaria densa (Hydrocharitaceae) in arctic and subarctic Iceland. New Journal of Botany 4:85-89.

Yarrow, M., Marín, V.H., Finlayson, M., Tironi, A., Delgado, L.E. \& Fischer, F., 2009. The ecology of Egeria densa Planchon (Liliopsida: Alismatales): A wetland ecosystem engineer? Revista Chilena de Historia Natural. 82: 299-313, https://doi.org/10.4067/S0716078X2009000200010. 